\title{
Determinates of Urban Poverty at Household Level: The Case of Wolaitta Soddo Town, SNNPRS, Ethiopia
}

\author{
Tamirat Tanga Tantasa, Dr. S.SIVAKUMAR \\ Hawassa University, College of Law and Governance, School of Governance and development Studies, \\ Department of Development Management
}

\begin{abstract}
Poverty is daily experience of citizens in Ethiopia and the government has implemented different poverty reducing policies and strategies in the intention to reach middle income countries in the coming 7 years. This Study aimed at analyzing the determinants of urban poverty At household level in terms of demographic, economic and social practices in soddo Town. The study was conducted under cross sectional research design. The approach that was used is a mixed approach which makes the use of both quantitative and qualitative methods. Samples of 227 households were drawn from the target population by adopting systematic random sampling technique and 18 of them were discarded from further consideration due to lack of response. Data collecting instruments like questionnaire, semi-structured interview, document analysis and focus group discussions were used to collect data. .A Logistic regression model was employed and estimated based on the primary data, with the probability of a household being poor as a dependent variable and a set of demographic and socioeconomic variables as the explanatory parameters. By making use of Food Energy Intake (FEI) approach the surveyed households are identified as the poor and non-poor. Based on this, Birr 3246 was computed as food poverty line per adult equivalent per month and out of the 209 respondent household heads, $94(45 \%)$ were found to be poor. The poverty gap index of 8 percent and poverty severity index of 3 percent were estimated. The variables that are positively correlated with the probability of being poor are family size whose number of members are 5 and above, education, age, sex, saving, electricity connection, unemployment and marital status. The variables that are negatively correlated with the probability of being poor are family size whose numbers of members are less than 5 , house tenure, water pipe connection, employment status. These calls for urgent interventions aimed at curbing the problems of the people through creating employment opportunities, family planning, provision of market based short term trainings, empowering females and distribution of social service, improving education services, health services, and creating access to credit facilities need to be promoted for poor urban household in the study area.
\end{abstract}

Keywords: - Poverty, poverty line, poverty incidence, poverty gap, poverty severity

DOI: $10.7176 / \mathrm{JAAS} / 60-02$

Publication date: January $31^{\text {st }} 2020$

\section{INTRODUCTION}

Poverty affects large proportion of the world's population. There are many part of each country of the world including the richest in spite of their wealth where poverty is the problem. It was estimated that about quarter of the world's population live in absolute poverty without adequate basic need (UN, 1996). Poverty in developing countries is characterized by mass poverty, which is explained as a situation where more than half of the total populations of the country lives in poverty, as the reality shows in any standard the greater parts of the population of the countries are unable to win their daily breads (Tizita, 2001).

In Ethiopia poverty is the general feature for the nation and causing many sufferings and anguish to the largest proportion of the population. It is high agenda of the government, donor agencies, NGOs and other actors that have the inspiration to reduce the level and mitigate the effect and its associated impacts on the wellbeing of the people. The Ethiopian government has been formulating and implementing various policy interventions and programs that are in one-way or another related with poverty reduction. The challenge in the struggle against poverty of the small sized towns in the country in general and in wolita soddo in particular is immense. One of the challenges in the struggle against poverty is clear identification of the prevailing impediments. Examination of some impeding variables which aggravate poverty is vital. Among the many impediments of poverty are the social, economic and demographic variables. Identifying their potential effects to poverty is critical in the study of urban poverty since these variables take the visible repercussions on the commendable life of urban dwellers. Poverty in Ethiopia is greatly connected with the size and composition of households, the educational level of household head, the degree and extent of dependency within the household, asset ownership, the occupation of household heads, rapid population growth, major health problems, lack of infrastructure and extreme environmental degradation (MoFED, 2012)

Looking at notable features of implications of urban poverty in Wolaita Soddo town, primarily housing problem is the major phenomenon in the town: There is a gap between a housing demand and supply, land lease price is very expensive for low and middle income societies. Moreover, the basic health services coverage of the town is only $84 \%$. Poor environmental sanitation and malnutrition among the poor are the major inducing factors 
for the debilitating effects of the diseases. Problems Associated with Electricity are: There are town roads, villages, households having power shortage (WSOoFED, 2018).

Present water supply coverage of the town as informed by the office is $76.4 \%$ ( town water supply office, 2017) from existing boreholes and spring (ground Water). The total telecommunication capacity is 22,240 and the city coverage is reached to $20.1 \%$ (ETC, 2017) other social problems are: the number of disables, the number of orphan children, elders without family support, and unemployment. The causes for these problems are lack of job opportunities, perception, economic, family disintegration, migration from rural to town, death of parents, natural and manmade accidents, and lack of awareness and poor use of protection. All the above problems in one or another way have implications of urban poverty in the town.

A number of studies has been conducted both in developed and developing countries regarding determinants of urban poverty at household level. In Ethiopia also several of studies were conducted in different aspects of urban poverty in different study areas. However, until now there is no research specifically conducted in the town regarding the determinants of urban poverty at household level, The aim of this study is, therefore, to assess determinants of urban poverty at household level in the town.

The general objective of this study was to analyze the determinants of urban poverty at household level, in Wolaita Sodo town. With the following specific objectives

1. To identify the factors determining poverty status of households.

2. To assess households social services in relation to poverty.

\section{RESEARCH METHODOLOGY}

\subsection{Research Design}

The research was conducted under cross sectional survey design. The unit of analysis for the research was a household and the data were collected at a single point in time as primary data set. The approach that was used is a mixed approach which makes the use of both quantitative and qualitative methods. Quantitative method is used to apply data collected through questionnaire. Qualitative method was used to describe and analyze the information that was obtained through, Interview and Focus Group Discussion.

\subsection{Data Type and Source}

Primary and secondary data from different primary and secondary sources were employed for this study.

\subsection{Sample Size Determination}

To determine the sample size of potential respondents of this study the households from each kebele were selected using (Cochran, 1997) formula. There are 10391 households in all Six (6) Kebeles. Out of which 1458 households are in Hibret, 1180 are in Giddo, 1626 are in Merkatogebeya, 2763 are in Wadu, 1879 are in Gola and 1485 are in Delebategle Kebeles.

The way how the sample size is selected as follows: $n=\underline{Z^{2} \times p \times(1-p) /} D^{2}$ : Where, $n=$ sample size. $Z=$ the statistics for the level of confidence at $95 \%$ confidence interval level (1.96), $\mathrm{P}=$ poverty prevalence rate / poverty head count ratio for urban centers in SNNPR, $D=$ Marginal error between the population and sample size (5\%), Therefore, 227 sample households were drawn from the target population

\subsection{Sampling Technique}

For the purpose of representative sample selection, the town was divided into two broad categories that are rural and urban areas. Ten (10) kebeles considered as rural and 11 kebeles are considered as urban. From urban cluster 6 kebeles were selected purposely, Selection criteria are made based on: Their common characteristic, past experience and Personal Judgment of the researcher and spatial distribution. Spatially, Giddo, Merkatogebeya and Hibret Kebele are center of their sub-city whereas Wadu, Gola and Delebategle Kebele taken as center-periphery. Numbers of households selected in each kebele were selected by using proportionate Population Size and Number of respondents from each kebels was selected using systematic sampling techniques.

\subsection{Method of Data Collection}

The research data collection instruments are very crucial to achieve the designed specific objectives and to respond the research questions. Thus, the survey questionnaires, Interview and Focus Group Discussion were applied to obtain this research study. Before starting the main data collection the pre-test was conducted to have guiding information from study area. Twelve enumerators were recruited from the study area based on education and experience. All interviewers and /or enumerators were trained for two days by the principal researcher on the administration of the questionnaire and two supervisors were recruited from the town for field supervision. 


\subsection{Method of Data Analysis}

\subsubsection{Identification of Poor Household}

The following three major steps were followed to identify poor household from the sample households:

\section{Step one: Selecting Monetary Indictor}

Among the two (income and expenditure) well know monetary indicators of poverty, this study took consumption as a measure of household poverty status with assumption that consumption works relatively well in the context of developing countries in measuring household poverty status (Ravillion1992). The definition of consumption under this research includes only bundles of 15 food items which are typically consumed by poor segment of Wolaita sodo Town residents and it does not include nonfood items as it is very difficult to get the precise data on nonfood consumption items. Moreover, expenditure on durable assets are not also included on consumption since the value of the services flow from ownership of the durable asset that should enter in to calculation of the aggregate expenditure( Deaton, 2002) .

\section{Step two: Setting Poverty Line}

As it is stated in literature section of the thesis, poverty line is the value of selected welfare indictor which separate poor household from non-poor households. The following major steps were involved in setting the poverty line for the study.

1. Defining the minimum daily energy intake which is $2200 \mathrm{kcal}$ which is recommended by WHO for health daily activity for Ethiopian

2. Identifying basket of food which consist 15 food item that are widely consumed by urban Ethiopian citizens

3. Scale the quantity in the food item in basket to correspond the $2200 \mathrm{kcal}$ requirement by using food conversion factor set by Ethiopian food composition table

4. Calculating the cost of the basket that yield the poverty line of the study area using the current market price of the food items and birr 3246 was found to be per adult equivalent consumption expenditure per month.

5. The food poverty line is Birr 3246 per month per adult equivalent

\section{Step Three: Identifying Poor Household from Non Poor Households}

To identify the poor households in study area the following seven steps are used.

Step one: This step is left for enumeration of food items consumed in the study area. The lists of food items included in the analysis are: Teff, Wheat, Maize, Barely, beans, peas, Lentil, vegetable (Cabbage, Carrot), Dry Pepper, Edible Oil, Cow Milk, Onion, Butter (Cow and Vegetable), Meat, and Sugar.

Step two: Each bundle of food item is weighted with the appropriate unit of measure (in Kilograms or litters). Step three: To get the total amount of food bundle a household consumed in a month each of the weighted bundles of food items are summed up. Teff, + Wheat + Maize + Barely + Potato + Onion + Beans + Peas + Vegetable ( fruits) + Dry Pepper+ Edible Oil+ Milk+ Butter (Cow and Vegetable) + Meat + Sugar. Mathematically it can be represented as, $\mathbf{K 1}+\mathbf{K} 2+\ldots+\mathbf{K n}$ (up to the last food item) where K refers to the value in kilogram or Litter of each food basket.

Step Four: The aggregate value of baskets of food items consumed by a household in a month is divided to the corresponding sample size of the household to get the amount of kilograms each adult individual gets in a month. Step Five: The amount of Kilograms each household consumes in a month is again divided for 30 days to get the amount of kilograms each adult individual consumed in a day.

Step six: The amount of kilograms an individual consumed in a day is again converted into calorie intake and is calibrated to the predetermined 2200 calorie per day per adult equivalent.

Step seven: This is the last step the research used to get the number of poor and non-poor households in the study area. The total calorie intakes of a household in a day divided by the family size of the surveyed household in the town, then calibrating the poverty line using the FEI international agreed figure -2200 calorie per day for an adult person as recommended by nutritionists,

\subsubsection{Model Specification}

Econometrics models are very useful tools that enable to assess the relationship between the regressed and explanatory variables and determine their significance. To determine the factors influencing urban poverty, I was employ the Logistic Regression model, with the dependent variable (Poor or non-poor) being dichotomous variable. If the explanatory variables are qualitative (categorical variable), the Logit model is the appropriate one (Gujirati, 2006).

The explanatory variables considered in the analysis are demographic (sex, age, marital status of the head, family size), educational level, occupation, house owner ship, water service, electricity and saving. Therefore, in the case of a binary poverty status (i.e. being poor or non-poor), let the underlying response variable $\mathbf{y}$ is defined by the regression relationship (Esubalew, 2006)

$y i=\alpha \mathrm{i} X i+v i$

Where: $y i$ is the status of household, $\alpha$ is set of coefficients, $X i$ is set of explanatory variables 
$v i$ is the error term and $\mathrm{i}$ represents households that run from 1 to $\mathrm{n}$

Thus, as y is latent variable, what is observable is an event represented by a dummy variable $d$

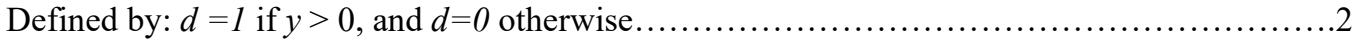

So, the response of the variable is binary, taking two values, 1 if the household is poor, 0 if not .The probability of being poor depends on a set of variables $\mathrm{X}$ so that, $\operatorname{Pr} o b(\mathrm{di}=1)=E(\alpha X)$ and

$\operatorname{Prob}(d i=0)=1-E(\alpha X)$

Where $\mathrm{E}$ is the cumulative distribution function for the error term $V i$ Therefore, our Logistic regression model is given by:

Logit $(p)=\operatorname{Ln}(p / 1-p)=\alpha 0+\alpha 1 \times 1+\alpha 2 \times 2+\alpha 3 \times 3+\ldots . .+\alpha n \times n$. .4

Where $\alpha 1, \alpha 2, \alpha 3 \ldots \ldots$ are the predictor variables ages of household, size of household, educational Level of the household head etc and $\mathrm{P}$ is probability that the household is poor.

Table 1.Discription of explanatory variables in the study

\begin{tabular}{|c|c|c|c|c|c|}
\hline Variable & $\begin{array}{l}\text { Varia } \\
\text { ble } \\
\text { code } \\
\end{array}$ & $\begin{array}{l}\text { Variabl } \\
\text { e Type }\end{array}$ & Variable Description & $\begin{array}{l}\text { Level of } \\
\text { measurem } \\
\text { ent }\end{array}$ & $\begin{array}{l}\text { Expected } \\
\operatorname{sign}(+/-)\end{array}$ \\
\hline Sex & Hsex & Dummy & $\begin{array}{l}\text { Sex of household head, } 1=\text { male and } \\
0=\text { Female }\end{array}$ & $\begin{array}{l}\text { Nominal } \\
\text { scale }\end{array}$ & $\begin{array}{l}\text { Negative/posi } \\
\text { tive }\end{array}$ \\
\hline Age & HAge & $\begin{array}{l}\text { Continu } \\
\text { ous }\end{array}$ & $\begin{array}{l}\text { Age of the household head in year } \\
1=31-40,2=41-60,3=\text { above } 60\end{array}$ & Ratio scale & $\begin{array}{l}\text { Negative/posi } \\
\text { tive }\end{array}$ \\
\hline family size & $\begin{array}{l}\text { Hfamsi } \\
\mathrm{z}\end{array}$ & $\begin{array}{l}\text { Continu } \\
\text { ous }\end{array}$ & $\begin{array}{l}\text { Total family members, } 1=1-2,2=3- \\
4,3=5-6 \text {. }\end{array}$ & Ratio scale & $\begin{array}{l}\text { Negative/posi } \\
\text { tive }\end{array}$ \\
\hline Education & $\begin{array}{l}\text { Hedule } \\
\mathrm{v}\end{array}$ & $\begin{array}{l}\text { Categori } \\
\text { cal }\end{array}$ & $\begin{array}{l}\text { Education level of household head } \\
1=\text { illiterate } 2=\text { primary, } 3=\text { secondar } \\
y, 4=\text { post-secondary }\end{array}$ & $\begin{array}{l}\text { Ordinal } \\
\text { scale }\end{array}$ & Positive \\
\hline Saving & Hsav & Dummy & $1=$ yes, $0=$ no & $\begin{array}{l}\text { Nominal } \\
\text { scale }\end{array}$ & positive \\
\hline Marital status & Hmar & Dummy & $1=$ married, $0=$ others & $\begin{array}{l}\text { Nominal } \\
\text { scale }\end{array}$ & $\begin{array}{l}\text { Negative/Posi } \\
\text { tive }\end{array}$ \\
\hline $\begin{array}{l}\text { occupation/Emplo } \\
\text { yment }\end{array}$ & $\begin{array}{l}\text { Hempl } \\
\text { o }\end{array}$ & $\begin{array}{l}\text { Continu } \\
\text { ous }\end{array}$ & $\begin{array}{l}1=\text { unemployed, } 2=\text { employed, } 3=\text { pe } \\
\text { nsioner }\end{array}$ & $\begin{array}{l}\text { Nominal } \\
\text { scale }\end{array}$ & Negative \\
\hline House Tenure & $\begin{array}{l}\text { Hhome } \\
\mathrm{T}\end{array}$ & Dummy & $1=$ own house, $0=$ otherwise & $\begin{array}{l}\text { Nominal } \\
\text { scale }\end{array}$ & Negative \\
\hline Access to Water & Awater & Dummy & $\begin{array}{l}1=\text { have private } \\
\text { water, } 0=\text { otherwise }\end{array}$ & $\begin{array}{l}\text { Nominal } \\
\text { scale }\end{array}$ & Positive \\
\hline $\begin{array}{l}\text { Access } \\
\text { electricity }\end{array}$ & Aelect & Dummy & $1=$ yes, $0=$ no & $\begin{array}{l}\text { Nominal } \\
\text { scale }\end{array}$ & Positive \\
\hline
\end{tabular}

\section{RESULT AND DISCUSSION}

The incidence of poverty is rampant among the surveyed households (45\%), 0.45 the head count ratio, 0.08 poverty gap, and 0.03 as the severity index in the town respectively calls for urgent interventions aimed at curbing the fate of the poor.

\subsection{Econometric Analysis}

Logistic regression analysis is used to identify the determinants of household poverty. Accordingly, it was found that two of them: family size and educational level are significantly affect households falling into poverty at $99 \%$ confidence level. Two of them: Home Tenure and saving are significantly affect households falling into poverty at $95 \%$ confidence level. Access of water, Access of electricity and household head sex are significantly affect households falling into poverty at $90 \%$ confidence level

\section{Model's Robustness (Predictive) Power}

The suitability of the chosen model for econometric analysis very much depends on how much it predicates from the actual observation or what percent of the actual observation is really predicted by the model. There are no fixed points as to judge the model as a best or bad predictor yet it is generally agreed that a model with its overall predictive power of fifty percent or more is good.

Therefore, to assess whether or not the model fits the data, the study used a prediction table (classification table) as shown in the table 4.13 on page 74 . The on and off-diagonals respectively tell the correct and incorrect 
number of predictions of the data. Thus, using these diagonals we can see how many households are correctly classified and how many are misclassified.

Table:2:Classification Table

\begin{tabular}{|l|l|l|l|}
\hline \multirow{2}{*}{ Observed } & \multicolumn{2}{|c|}{ Predicted } & \\
\hline & \multicolumn{1}{|c|}{ Poverty Status } & Percentage \\
\hline Non Poor & Non Poor & Poor & 86.1 \\
\hline Poor & 99 & 16 & 79.8 \\
\hline Over all Percentage & 19 & 75 & 83.3 \\
\hline
\end{tabular}

Source: Own Survey and Computation,2018

The diagonal entries of the table 4.13 show that 75 out of 94 households who live below the poverty line are correctly predicted. Similarly, the model correctly predicted 99 out of 115 households who live above the poverty line.

On the other hand, the off-diagonal entries of the table show that 19 households who live below the poverty line and 16 households who live above the poverty line respectively are incorrectly predicted.

From a total of 94 households who live below the poverty line 79.8 percent were correctly predicted and out of 115 households who live above the poverty line 86.1 percent were correctly classified. Generally, 83.3 percent of the 209 valid cases were correctly predicted. Therefore, the model is appropriate for the data.

\section{Odds and Marginal Effects}

Odds of the model tell by what factor the dependent variable change does whenever a unit change occurs in an independent variable. Odds ratio is the Log value of odds and is always positive. In this particular study it is found out that the odds ratio, the ratio of the probability of being poor to the probability of non-poor, is $0.82,(94 / 115)$. Marginal effects refer to the additional value to the dependent variable given an increase or decrease on the explanatory variable.

The first, second, and third columns of the table 4.14 on page 76 respectively represents the independent variables, odds (coefficient of predictors) and standard error. The third, fourth, and six columns of the table depict Wald which is obtained by dividing odds ( $\mathbf{B})$ to standard error and squaring the value ( $\mathbf{\beta} / S E)$ ) , significance level of each independent variable on urban poverty and exponent of $\boldsymbol{\beta}$ in order.

In most econometric analysis the most important variables used are the odds, significance levels and odds ratio (exponent of $\mathbf{\beta}$ ). 
Table 3 Logit maximum-Likelihood estimates

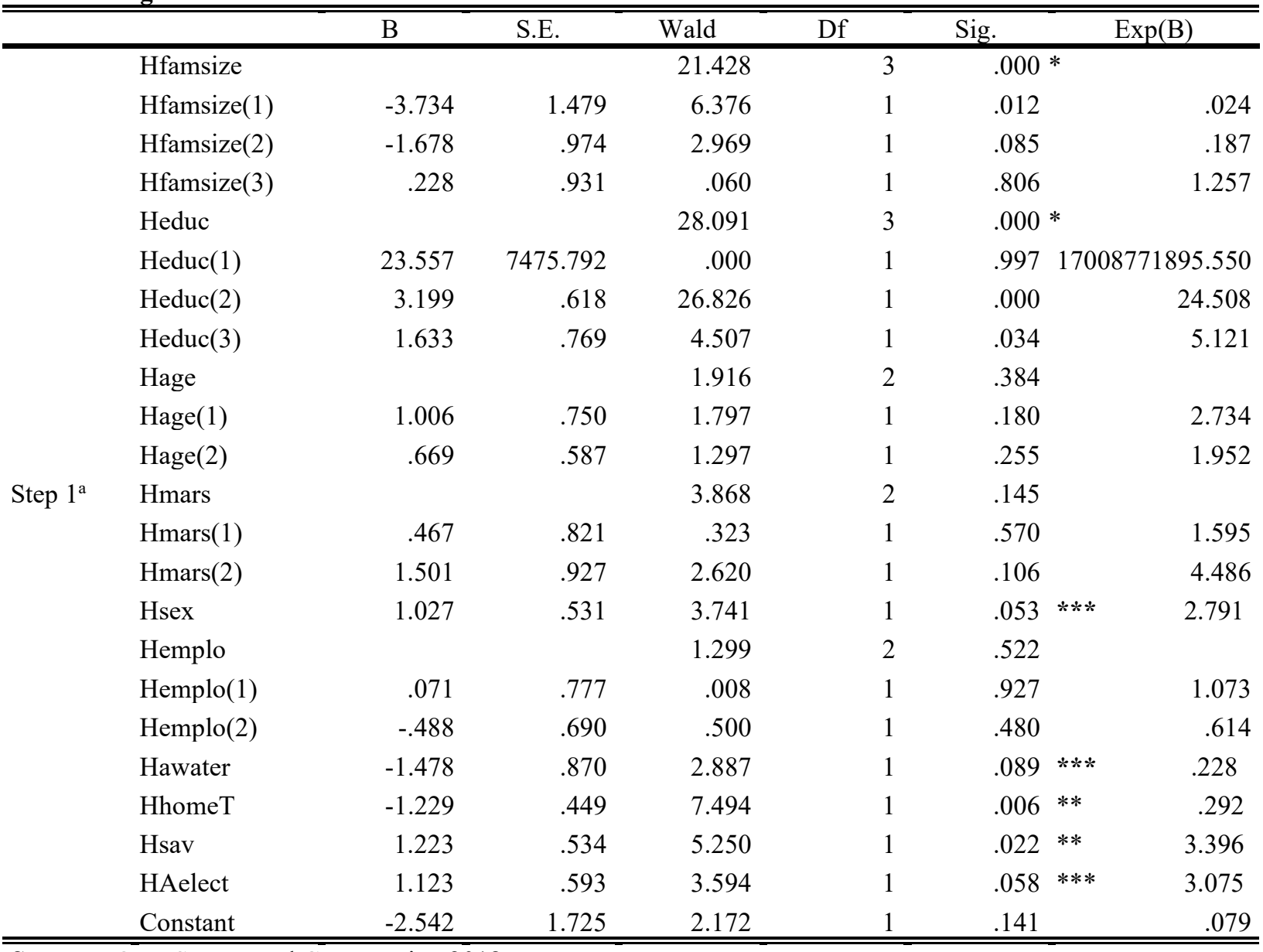

Source:- Own Survey and Computation,2018

Note. * Significant at $\mathrm{P}$ value $<1 \%$, ** significant at $\mathrm{P}$ value $<5 \%, * * *$ significant at $\mathrm{P}$ value $<10 \%$ and unmarked variables are insignificant

Source: Own survey and computation,2018

Examination of the table 3, Logit maximum-Likelihood estimates demonstrates that the variables that are positively correlated with the probability of being poor are :.Family size (the number of family members greater than or equal to 5), Level of education Household head Age, sex of household head, Saving habit, Access of electricity Unemployment status and Marital status and the variables that are negatively correlated with the probability of being poor are Family size (the number of family members less than 5), Household head Sex, Employment status and House tenure.

The probability that a household with the number of family members of 1 to 2 and 3 to 4 are negatively related with poverty and the number of family members 5 to 6 is positively related with poverty. The odds ratio of being poor for household with family size of 1 to 2 are $2.4 \%$ less likely than the reference category(family size above 6 ) and the odds ratio households being poor with family size of 3 to 4 are $18.7 \%$ less likely than reference group. Also the odds ratio households being poor with family size of 5 to 6 are $125.7 \%$ less likely than reference group It is evident that family size can affect the household poverty status directly as a larger family sizes means larger expenditures for food, clothing and shelter, education, health and other needs. It is, therefore, easy to understand that as size of family increase, with no corresponding increment the income of the household, the household highly prone to fall in to poverty or remained trapped under poverty.

It is evident from the table 3 that the probability that household's education level is positively related with poverty and primary educational level of the household head has significant relationship with the response variable. According to binary logistic regression analysis, the odds ratio of the household headed by illiterate household head are very large times more likely to be poor than households headed by post-secondary educational level. The odds ratio of household headed by household head who have primary level education is 50 times more likely to be poor than households headed by post-secondary educational leve1. The odds ratio of household headed by household head who have secondary level education is 24.504 times more likely to be poor than households headed by post-secondary educational level. 
The probability of household sex is positively related with poverty status. Household head sex found to be determinant in poverty status of a household under the study. The odds ratio of being poor for households that have male sex are 2.791times less likely be poor than the reference category (female sex). The positive value of odds in household head sex indicates that as female heads the household the probability that a household falls into poverty increases.

Access to electricity is found to be determinant in poverty status of a household under the study and the probability that household's access to electricity is positively related with poverty. The odds ratio of being poor for households that having access of electricity at their home are 3.075times less likely be poor than the reference category.

It is evident from the table 3 that the probability that household's marital status is positively related with poverty .The odds ratio being poor for households headed by married household head are 1.595times more likely than reference category (widow) and The odds ratio being poor for households headed by divorcee household head are 4.486times more likely than reference category. Therefore, households headed by married household were found to be in better off condition in contrast to those households headed by divorce and widowed household heads. This is due to the fact that when people get married household size will increase as new children are born and expenditures increase which in turn leads to searching for mechanisms of fulfilling additional needs and necessities for the family.

The probability of household employment status is negatively related with poverty status. The odds ratio of being poor for households which is headed by unemployed are 1.073 times more likely than the reference category(pensioner) and the odds ratio being poor for household headed by employed are 0.614 times more likely than the reference category.

The probability of household saving habit is positively related with poverty status. Household saving habit found to be determinant in poverty status of a household under the study. The odds ratio of being poor for households that have a saving habit are 3.396times less likely be poor than the reference category (no saving habit). This mainly due to the fact that willing to save for future consumption depends on current income level and in poor household where most income have to spent on consumption, they don't afford to plan for saving.

Access to water is found to be determinant in poverty status of a household under the study and the probability that households who do have private tape water in their compound are negatively related with poverty .The odds ratio of being poor for household who do have private tape water in their compound are 0.228 times less likely be poor than the reference category.

Household House Tenure is found to be determinant in poverty status of a household under the study and the probability that households who do have their own house are negatively related with poverty. The odds ratio of being poor for household who do have their own house are 0.292 times less likely be poor than the reference category.

It is evident from the table 3 that the probability that age of household head is positively related with poverty. The odds ratio being poor for households headed by age ranges of 31 to 40 are 2.734times less likely than reference category (above 60) and The odds ratio being poor for households headed by age ranges of 41 to 60 are 1.952 times more likely than reference category.

\section{CONCLUSION}

- Households with larger family size have greater probability of falling in to poverty.

- Being in a household of female-headed one is more vulnerable to the prevalence of poverty in than those of male headed ones.

- Household headed by relatively high level of education tend to be less poor than those household headed by low level of education status

- Households that have no saving habit are greater probability of falling in to poverty

- Households who do have no their own house, no private tape water in their compound, no access of electricity are greater probability of falling in to poverty.

- The variables that are not significantly correlated with poverty are Age, Marital status and Employment

- The variables that are positively correlated with the probability of being poor are :.Family size (the number of family members greater than or equal to 5), Level of education Household head Age, sex of household head, Saving habit, Access of electricity Unemployment status and Marital status.

- The variables that are negatively correlated with the probability of being poor are Family size (the number of family members less than 5), Household head Sex, Employment status and House tenure.

- The variables that are significantly affect households falling into poverty at $99 \%$ confidence level are Family size and Educational level.

- The variables that are significantly affect households falling into poverty at $95 \%$ confidence level are saving and House tenure.

- The variables that are significantly affect households falling into poverty at $90 \%$ confidence level are 
access of electricity, Household head sex and Access of water.

\section{RECOMMENDATIONS}

Based on the findings above the researcher recommended the following important points

- The study found out that female-headed households are more likely to be poor than households of which the head is male. The odds ratio of being poor for households that have male sex are 2.791 times less likely be poor than the reference category (female sex) The implication is therefore that promoting female related things should be an important element of poverty reduction policies.

- The odds ratio of being poor for household with family size of 1 to 2 are $2.4 \%$ less likely than the reference category(family size above6) and the odds ratio of households being poor with family size of 3 to 4 are $18.7 \%$ less likely than reference group. Also the odds ratio households being poor with family size of 5 to 6 are $125.7 \%$ less likely than reference group. This has a clear implication for the residents of the town in that households with large size will fall into the hardcore sections of poverty easily than those who have not. Thus, in order to minimize such effects, family plans and/or education of couples be provided by the concerned bodies. In this regard the town's health service can play a vibrant role.

- The study found out that household headed by currently not married are more likely to be poor than households of which were headed by married household. The implication is, therefore, preventing family from divorce should be an important element of poverty reduction policies.

- The study found out that household that did not saving have more likely to be poor than those holds which did make saving. Therefore, community level education and awareness creation programs need to conducted in the Town so as to enhance the habit of saving among the neighborhoods.

- Efforts should be made to reduce housing shortage; overcrowding, rents affordable relative to income, water and sanitation facilities must be improved by reallocating and increasing funds.

- That the educational attainment of the head of the household is found to be the most important factor associated with urban poverty clearly suggests ways of focusing on the value of education. Adequate education is central in addressing incidence of poverty.

- Although employment was found insignificant indicator of poverty it at least is correlated negatively. In the town the issue of unemployment according to the survey results is not that much serious. The paradox is, nevertheless, that even the employed ones are not able to lead commendable lives. This is because the return they get is not sufficient. This shows that the situation of unemployment should be revisited again. Wage and salary should be adjusted consistently with the rise in the standard of living for civil servants and daily workers

- $\quad$ Addressing urban poverty will take more than encouraging employment. Increased safety nets to support those who do not participate in the urban labor market are (elderly, disabled, female headed households) needed.

- $\quad$ The variables that are not significantly correlated with poverty (in the Logit model) are Age, Marital status and Employment. This doesn't, however, to mean that they are unimportant parameters of poverty but are not as desperately needed at this time for poverty analysis as the other variables do. They need to be strengthened in the future.

- In general, the problem of poverty in the town can be reduced to a significant level so long as there are joint efforts in the identification of the causes, consequences, and commitments in the implementation from the government, NGOs, researches by professionals, the poor themselves, and from any interested stakeholder(s).

\section{SUGGESTION FOR FURTHER RESEARCH}

- Construction of comprehensive poverty profiles at the town level is vital but the task could only be possible if there is commitment from the government, town administrators, NGOs, researchers, the residents and any concerned body. This research is cross-sectional which only can tell a result of one time survey. The availability of panel data is, therefore, badly needed in order to be able to construct better models of the determinants of poverty in the town.

- $\quad$ The study assessed the incidence of poverty in the selected Kebeles at a household level. It only can tell the incidence of poverty based on these households. It is of the writer's feeling that future studies should study the town's poverty other than the household level so as to get a wider view of poverty profiles and policy implications. This could be seen from the institutional, social, gender, and extra perspectives.

- The study employed the FEI approach in the identification of the poor from the non-poor. The validity of this research could be testified if other approaches are applied. Therefore, methods other than the ones developed should be incorporated in other studies in the future. 


\section{REFERENCES}

Alemayehu G., Niek de Jong, Kimenyi M.S., Mwabu G., 2005 Determinants of Poverty in Kenya: A Household Level Analysis, working paper 2005-44, Nairobi, Kenya

Asmamaw Enquobahrie (2004).Understanding Poverty: The Ethiopian Context. A Paper presented at The Gambia AAPAM Roundtable Conference, Banjul, and the Gambia: pp 2-4.

Daneil Gebretsadik.2001. Urban poverty and housing condition of the poor in Addis Ababa: A case Study in selected kebeles in Addis Ababa, Master's Thesis. Addis Ababa University

David Elesh. 1970. Poverty Theories and Income Maintenance. Institute for Research on Poverty at The University of Wisconsin: pp1-6.

Dercon, S., and M. Tadesse. 1999. “A Comparison of Poverty in Rural and Urban Ethiopia.” Ethiopian Journal of Economics 8, no. 1: 83-98.

Esubalew Alehegn. 2006 Determinants of Urban Poverty in Debre Markos, Ethiopia: A Household Level Analysis. M.Sc Thesis in Regional and Local Development studies, Addis Ababa University, Ethiopia: pp 1-15.

Fitsum, T., 2002. Poverty in Addis Ababa: A comparison of female and male headed Households, Master's Thesis, Addis Ababa University

FSS .2003. Some aspects of Poverty in Ethiopia: Three Selected Papers, Studies on Poverty No.15 Addis Ababa. Ethiopia.

Gaurav, D.,Simler, K. R., Mukherjee, S.,2000. Determinants of poverty in Mozambique: 1996- 97, FCND Discussion Paper No. 78; Food Consumption and Nutrition Division, International Food Policy Research Institute, Washington, D.C.

Gebremedhin, T., and Whalen S., 2006.Prices and Poverty in Urban Ethiopia: Journal of African Economies, 17(1)

Mekonnen, T.,1999.Determinants and Dynamics of Urban Poverty in Ethiopia, Ethiopian Journal of Economics, Ethiopian Economic Association, Vol. VIII, No. 1:61-81.

Meron A. (2002). Gender Dimensions of Urban Poverty in Ethiopia: The case of three kebeles inAddis Ababa. Forum for Social Studies

MoFED (2002). Ethiopia: Sustainable Development and Poverty Reduction Program. July, Addis Ababa, Ethiopia

MoFED (2006). Ethiopia: Building on Progress- A Plan for Accelerated and Sustained Development to End Poverty (PASDEP) 2005/06-2009/10, Volume I, September, Addis Ababa, Ethiopia

MoFED (2012). Growth and Transformation Plan 2010/11-2014/15, Main Document, Volume I, Available online at: http://www.mofed.gov.et [Accessed on January 12, 2012].

MoFED (2012b). Ethiopia`s Progress Towards Eradicating Poverty: An Interim Report on Poverty Analysis Study (2010/11), May, Addis Ababa

Mohammed, B. (2017). Measurement and Determinants of Urban Poverty in Case of Southern Nations, Nationalities, and Peoples' Region (SNNPR), Ethiopia

National Economic Council (NEC), the National Statistical Office (NSO), the International Food Policy Research (IFPR), 2001. The Determinants of poverty in Malawi (1998): An analysis of the Malawi Integrated Household Survey, 1997-98, Malawi.

Ravallion (1993). Poverty Comparisons, Fundamentals of Pure and Applied Economics Vol 56. Harwood Academic Press, Switzerland

Ravallion, M., and B. Bidani. 1994. "How Robust is a Poverty Profile?" The World Bank Economic Review 8, no. $1: 75-102$.

Saith, A (2005). Introduction to Poverty Analysis. World Bank Institute

Sen, A.K (1987). The Standard of Living. Cambridge University Press

Somashekar, T (2003). Development and Environmental Economics. New Age International PLtd Publishers, 1 st edition. India

Spaho, A. (2014). Determinants of Poverty in Albania. Journal of Educational and Social Research ,Vol. 4 No.2 p157.

Tadesse, M. 1996. "Food Consumption and Poverty in Urban Ethiopia: A Preliminary Assessment." In Proceedings of the Fifth Annual Conference on the Ethiopian Economy, ed Kebede, B., and M. Tadesse. Addis Ababa.

Tesfaye Alemayehu. 2006. The Analysis of Urban Poverty in Ethiopia. The University of Sydeny, Australia: pp $2-8$

Tesfaye Alemayehu 1999. "Determinants and Dynamics of Urban Poverty in Ethiopia." Ethiopian Journal of Economics 8, no. 1: 61-82.

Tizita Mulugeta .2001. Urban poverty: Comparative analysis of female and male headed households Woreda2 and 28, Master Thesis Addis Ababa University.

UNDP (1997) Human Development Report 1997, New York.

United Nations,2014.World Urbanization Prospects: New York

Walton Michael (1998), Will Global Advance include the World's Poor? In: Bearg Dyke Nancy (ed.), Persistent 
Poverty in Developing Countries. Determining the Causes and Closing the Gaps, Aspen Institute, Washington, pp.7, $81-99$

World Bank. 1990. World Development Report 1990: Poverty. Washington, DC: World Bank.

World Bank 2000. World Development Report 2000/2001: Attacking Poverty. Washington, DC: World Bank.

WB. 2015. Ethiopia Urbanization Review: Urban Institutions for Middle Income Ethiopia. Washington DC: pp 410.

WBI (World Bank Institute), 2005).Introduction to Poverty Analysis; Poverty Manual, All, JH Revision World Bank 2000. World Development Report: Attacking poverty: New York, Oxford University Press. World Bank 1999. 'Ethiopia: Poverty and Policies for the New Millennium' Draft.

Yassin W.1997. Poverty in Addis Ababa: A Case Study of selected Kebeles in Eastern Addis Ababa, M.A. thesis, Department of Geography, Addis Ababa University: pp 12.

Yohannes Kinfu.1996. Demographic Characteristics of poor his in urban Ethiopia: The case of Dire Dawa Town 